\title{
COMPOUND WORDS THAT OCCUR DURING THE GLOBAL PANDEMIC COVID-19: A MORPHOSEMANTIC STUDY
}

\author{
Ervina CM Simatupang \\ English Department, Widyatama University, Indonesia \\ E-mail: ervina.simatupang@widyatama.ac.id \\ Ida Zuraida Supri \\ English Department, Widyatama University, Indonesia \\ E-mail: ida.zuraida@widyatama.ac.id
}

\begin{abstract}
APA Citation: Simatupang, E. C., \& Supri, I. Z. (2020). Compound words that occur during the global pandemic covid-19: A morphosemantic study. English Review: Journal of English Education, 8(2), 291-298. doi: 10.25134/erjee.v8i2.2824.
\end{abstract}

\begin{abstract}
This study aims to analyse and examine closely the category of compound words that occur during the global pandemic COVID-19 and their type of meaning. The method used in carrying out the study was a descriptive analysis method. The data used were taken from the official website of the World Health Organization (WHO) in the 'Your Questions Answered' section. The results demonstrated that there are two types of compound word found, namely compound nouns (67\%) and compound verbs (33\%). Besides, there are three types of meaning found, namely literal meaning (50\%), semi-idiomatic meaning $(33 \%)$, and idiomatic meaning (17\%). Furthermore, in the category of compound nouns, the types of meaning that occur are literal meaning (50\%), semi-idiomatic meaning (25\%), and idiomatic meaning $(25 \%)$. Meanwhile, the types of meaning that appear in the category of compound verbs are literal meaning $(50 \%)$ and semi-idiomatic meaning $(50 \%)$.
\end{abstract}

Keywords: COVID-19; coronavirus disease; compound words; meaning; word formation.

\section{INTRODUCTION}

Currently, the world is facing and struggling with a new virus that has been announced as a global pandemic by the World Health Organization (WHO) on March 11, 2020 that is the coronavirus disease, COVID-19. After first found as an unknown pneumonia disease on 31 December 2020 in Wuhan, China, according to the Situation Report - 116 published by WHO on 15 May 2020, a total of 4.338 .658 cases have been confirmed in more than 200 countries. As the virus progresses, every day, the world's community is introduced to terms that may sound unfamiliar. After going through the WHO official website, the terms found are commonly constructed in a form of compound words.

Commonly, a compound or compound word is regarded as a phrase that is constituted by the combining of two words. It is in line with McManis et al., (1987) stating that a compound is a word formed by the combination of two independent words.

On the contrary, according to Spencer and Zwicky (2001), a compound is a word that consists of two or more words. Furthermore, Akmajian et al., (2001) explain that "compounds are not limited to two words". Similarly, Leech
(1974) emphasizes a similar definition in which he states a compound is a word which contains two or more other words. In this regard, as this study progresses, the term compound is used to refer to the word combination that consists of two or more words.

Further, as stated by Yule (2006), the process of combining two or more words is known as compounding. It is one of the types of word formation and arguably the most common one.

As the coronavirus pandemic goes on, the terms emerge with it are countless starting from medical scientific terms, i.e. coronavirus disease, incubation period, to slangs that the community establishes, namely quarantine. It is a slang term for a cocktail people drink, martini (a cocktail made with gin or vodka and dry vermouth served with either a green olive or lemon peel), that is blended with the word quarantine as people could not go out to drink and instead drink at home.

Conceivably, terms that are occurring are not only caused by the new virus that needs certain terms for the medical or scientific matters, but it is also because of the 'new normal' that people are being forced into. The 'new normal' also brings terms like work-from-home, stay-at-home, and self-quarantine as the state mandates people 
to have less physical contact. Presumably, people are also trying to find new ways to get through the pandemic as it has been going on for around five months now.

The phenomenon of creating and forming new terms/words during COVID-19 can be studied through two of the linguistics branches, namely morphology and semantics. One branch of linguistics that studies the structure of a word and its formation process is referred to as morphology. Etymologically, morphology derives from the Greek word 'morph' which means shape or form. It is the system of categories and rules involved in word formation and interpretation as described by O'Grady (1997). Furthermore, it is defined as a study of the way words are built up from smaller parts (Burling, 1992). Similarly, Bauer (1988) says that as a sub-branch of linguistics, morphology deals with the internal structure of word-forms. This is also comparable with the statement of Payne (1997) that "morphology is the study of the internal structure of words". Additionally, morphology includes the constructions of words and parts of words. Spencer (1999) argues that "morphology is at the conceptual centre of linguistics." It is due to what morphology studies, that is the structure of words. Specifically, Aronoff and Fudeman (2005) assert that morphology is the study of form or forms. Linguistically, it refers to the mental system contained in word formation, its internal structure, and how it is formed. Hence, based on those definitions, it can be concluded that morphology is the analysis of word structure which involves the internal structure of words, the processes, and the rules to form them.

In morphology, it is known that the smallest unit to be analysed is a morpheme. According to O'Grady (1997), there are two types of morphemes, namely free morpheme and bound morpheme. Free morpheme has its meaning by itself, while bound morpheme has to be attached to another root to have a meaning. In other words, it can be said that free morphemes are roots (the simplest form of a word with no affix attached) and bound morphemes are affixes.

According to Yule (2006), there are seven morphological processes that can affect morphemes and therefore form new words, namely:

1) Affixation - According to Chaer (2003), affixation is the process of attaching affixes to roots. For example, the word manager (manage + -er) has experienced an affixation process particularly suffixation. It is the addition of an affix at the end of a root. This process cause changes in the class of words, namely from a verb (manage) to a noun (manager).

2) Compounding - Yule (2006) mentions compounding is a process of combining two or more words. In other words, it is the process of putting words together to build a new one that does not denote two things, but one. Arguably, compounding is one of the most common ways to form words. Moreover, Williams (1975) emphasizes that compounding is the process of putting together two or more independent words to make one word.

3) Blending - This process concerns the formation of words whereby new words are formed by combining parts of two words; for example, smog (smoke + fog), brunch (breakfast + lunch), and newscast (news + broadcasting).

4) Clipping - Clipping is the process of shortening a word to form a new word. The shortened form represents the word in its entirety. It is considered less formal and in some cases, the spelling is adapted to suit the pronunciation. For instance, nark for narcotics or bike for bicycle.

5) Back-formation - It is the process in which new words are formed by the deletion of a supposed affix from an already existing word, which appears to be derivative, e.g. laze from lazy, edit from editor, and enthuse from enthusiasm. This process is more likely to cause a class of word change.

6) Conversion - Conversion is the process of forming new words by shifting the word category without necessarily changing the word. In other words, it is assigning an already existing word to a new syntactic category. For instance:

I use comb after a shower - comb (noun)

I comb my dog's hair - comb (verb)

7) Acronym - Acronym is the process whereby a new word is formed through extracting the initial letters of the constituent words of a phrase. The words created from this process mostly function as nouns, e.g. NASA (National Aeronautics and Space Administration) and VIP (Very Important Person).

As one of the common ways in morphological processes, compounding has served the community to extend their creativity in creating new words by combining words. However, two or 
more words combined can be misinterpreted as a phrase (Quirk et al., 1985). There are seven characteristics of compounds, as follows: 1) Compounds behave grammatically and semantically as single words; even though on a lexical level, each constituent has its meaning; 2) They have no affixes attached except for inflectional suffix, e.g. bathrooms; 3) The whole meaning of the compound word can often be obtained from the individual meaning of each component, e.g. boathouse which means a shed for storing boats. However, certain terms cannot be interpreted the same way; for example, the word 'redcoat' means a British soldier, not a coat that is red; 4) The second or the last element of the compounds usually determines the grammatical category of a compound. This is also called the headword; 5) Compounding is a recursive process in which it may be a part of a larger compound, e.g. lighthouse keeper; 6) Phonologically, the primary stress of a compound is on the first element; and 7) A compound can be written in three different ways: open (with a space separating each constituent), e.g. post office; hyphenated (with a hyphen in between), e.g. twoyear-old; and closed/solid compound (with no space or hyphen in between), e.g. beeswax.

In addition to having those characteristics, compounds are also distinguished based on categories. According to Katamba (1993) compounds can be put into three categories, as follows:

1) Compound Nouns - derive from two or more words combined that function as nouns. Compound nouns can be formed by putting together words in category either Noun $(\mathrm{N})+$ Noun $(\mathrm{N})$, Adjective (A) + Noun (N), Preposition $(\mathrm{P})+$ Noun $(\mathrm{N})$, or Noun $(\mathrm{N})+$ Adverb (Adv). For example, skyline $(\mathrm{N}+\mathrm{N})$, sourdough $(\mathrm{A}+\mathrm{N})$, undergraduate $(\mathrm{P}+\mathrm{N})$, and hanger-on $(\mathrm{N}+\mathrm{Adv})$.

2) Compound Verbs - are formed by the combination of two or more words that grammatically function as verbs. The common combinations are Preposition $(\mathrm{P})+$ Verb (V), Verb (V+V), and Verb + Preposition $(\mathrm{P})$. For instance, underestimate $(\mathrm{P}+\mathrm{V})$, cross-check $(\mathrm{V}+\mathrm{V})$, and turn off $(\mathrm{V}+\mathrm{P})$.

3) Compound Adjectives - are modified by combining two or more words which as a unit function as adjectives. This combination can be done by combining Noun $(\mathrm{N})+$ Adjective (A), Adjective (A) + Adjective (A), and Preposition (P) + Adjective (A). For example, user-friendly $(\mathrm{N}+\mathrm{A})$, short-lived $(\mathrm{A}+\mathrm{A})$, and outspoken $(\mathrm{P}+\mathrm{A})$.

As it has been mentioned earlier, the terms introduced during this time are mostly found in a form of compounds. A compound is one of the topics discussed in morphology concerning wordformation or morphological process. Compound words on a lexical level have their meaning; while being combined they can either add other meaning to one of the words or form a different meaning. For example, the word medical mask adds another meaning to the word mask that is the type of mask, which can be a cloth mask or a surgical mask. On the contrary, the words 'flulike' or 'influenza-like' do not add another meaning to one of the words, instead, they form a new meaning that is the symptoms similar to flu or influenza including fever, cough, runny nose, headache, and fatigue.

On the other hand, semantics is the study of meaning in human language (O'Grady, et al., 1997). Additionally, Palmer (1983) emphasizes that semantics is the technical term used to refer to the study of meaning. Similarly, according to Hurford (2007), semantics is the "study of meaning in language". Therefore, it can be concluded that semantics is the term used to denotes the study of language meaning.

As the study of meaning, semantics is the centre of the study of communication (Leech, 1981). This explanation is due to the increasing cruciality of communication and with that comes the necessity to understand language and its meaning deeper.

O'Grady, et al. (1997) notes meaning is the message conveyed by signs. They can be something spoken, written, or expressed in other ways (Quirk et al., 1978). In other words, Simatupang (2019) elaborates that semantics is the science of the meaning of words and sentences. From those definitions, it becomes clear that in semantics, meaning is an immensely important part. Nevertheless, semantics as the study of meaning is frequently intertwined with another branch of linguistics that also studies meaning, pragmatics.

The distinction between the two primarily relies on which meaning one holds. Semantics discusses meaning in the language, the meaning as the language suggests. On the contrary, pragmatics holds meaning from the speaker's point of view or known as the speaker's meaning (Yule, 2006).

Semantically, Leech (1981) divides meaning into three types, namely conceptual meaning 
(meaning that consists of primary concepts), associative meaning (figurative meaning), and thematic meaning (meaning defined by structure to deliver a certain message, e.g. emphasizing). On the contrary, Downing (2006) states that meaning can be divided into three types, namely literal meaning (original or lexical meaning), the semi-idiomatic meaning (consists of at least one literal and one figurative meaning), and idiomatic meaning (non-literal meaning).

This study is carried out using the data from the 'Your Questions Answered' section on the WHO official website. As the pandemic continues, more unreliable sources of information are spread. Therefore, the WHO official website is used as the main data source to avert any mislead. It is found to be unethical to use inaccurate data as they can cause panic and fright.

Hence, this study aims to discuss thoroughly the category of compound words related to COVID-19 found in the 'Your Questions Answered' section on the World Health Organization (WHO) official website and the meaning of the compound words. Simply put, the problems discussed in this study are formulated into the following questions: 1) What is the category of the compound words related to COVID-19 found in the 'Your Questions Answered' section on the World Health Organization's official website? And 2) What is the meaning of the compound words found?

\section{METHOD}

This study aims to analyse the compound words related to COVID-19 found in the "Your Questions Answered' section on the official website of the WHO, https://www.who.int/ that are last retrieved on 14 May 2020. The method used in conducting the research was a descriptive analysis method. Trochim (2006) explains that the descriptive analysis method is used to illustrate the basic features of the data in a study. In this way, this method provides simple summaries. Furthermore, Whitney (1960) mentions that the descriptive method is carried out by the presence of facts analysed with correct interpretations. Similarly, Nazir (2006) states that it is a method in examining the case of a group of people, an object, a set of conditions, a system of thought, or a class of events in the present. This descriptive study illustrates or paints systematically, factually, and accurately the facts and the relationship between the phenomena. In other words, the approaches used in this study are classifying, analysing, and explaining the data obtained according to the theories related to compound words and meaning.

\section{RESULTS AND DISCUSSION}

After analysing the compound words found in the 'Your Questions Answered' section on the WHO official website, there are three types of compound words identified, namely Compound Nouns, Compound Verbs, and Compound Adjectives. Thereafter, this study also discusses the meaning of the compound words on a lexical level and their type of meaning after having experienced compounding. The main theories used in this research dealing with compound words are taken from Katamba (1993), and regarding the semantics view, it will be viewed according to Downing (2006). The followings are the data based on the types of compound words found in the data source.

\section{Compound nouns}

Data \#1

"What is a coronavirus?"

(WHO, 2020, Q\&A on coronaviruses (COVID-19))

From the data, the compound word found is coronavirus. Morphologically, coronavirus represents the type of compound nouns due to the combining of the word corona and virus, which are in the category of noun + noun.

Semantically, on a lexical level, corona has mainly two different meanings depending on the field in which it is being used. In terms of environment, corona means a circle of light that can sometimes be seen around the moon at night, or around the sun during an eclipse or the outer atmosphere of a star as defined by Cambridge Dictionary. In terms of anatomy, corona means the top rounded part of a body part, such as a tooth or the skull. The word virus has the meaning of an extremely small piece of organic material that causes disease in humans, animals, and plants.

However, the two meanings of corona have shown no relationships with any sort of virus. This is because the word corona in coronavirus does not derive from English, instead it derives from Latin. In Latin, corona means crown. This name is given since coronavirus seen under a microscope has a series of crown-like spikes on its surface.

WHO mentions coronavirus to regard to the large family of viruses that may cause illnesses, specifically respiratory infections ranging from the common cold to more severe diseases. The 
ENGLISH REVIEW: Journal of English Education

Volume 8, Issue 2, June 2020

previously known coronavirus diseases include Middle East Respiratory Syndrome (MERS) and Severe Acute Respiratory Syndrome (SARS).

For this reason, the word coronavirus carries the semi-idiomatic meaning in which it has one literal meaning that is virus and has one figurative meaning that is corona.

Data \#2

"Follow national guidance on self-isolation"

(WHO, 2020, Q\&A on coronaviruses (COVID-19))

The compound word found in data 2 is selfisolation. This compound word formed by the combination of the word self and isolation holds the category of compound nouns. It is because the word self is in the word category of nouns and so does the word isolation. Therefore, it is formed by the combination of two nouns.

The word self on a lexical level means oneself or itself or of oneself or itself. Meanwhile, the word isolation means the action of isolating or the condition of being isolated. Furthermore, WHO defines self-isolation as an act of separating people who are ill with symptoms of COVID-19 and may be infectious to prevent the spread of the disease.

Based on the meaning of the two words combined, it can be concluded that the word selfisolation presents a literal meaning.

\section{Data \#3}

"In the lockdown, I am spending much more time online playing games, socializing, and studying. Should I be worried about this?"

(WHO, 2020, Q\&A: Adolescents, youth and COVID-

From the data above, the compound word found is lockdown. It is formed by combining the word lock and down. The word lock is in the word category of nouns. On the contrary, the word down is in the word category of adverbs. Therefore, lockdown is the combination of a noun and an adverb. In this case, lockdown falls into the type of compound nouns.

On a lexical level, the word lock means $a$ fastening (as for a door) operated by a key or a combination. Additionally, the word down means toward or in a lower physical position. However, the combination of the two does not represent the meaning of a fastening operated by a key or a combination toward a lower physical position. On the opposite, lockdown means the confinement of prisoners to their cells for all or most of the day as a temporary security measure or a temporary condition imposed by governmental authorities (as during the outbreak of an epidemic disease) in which people are required to stay in their homes and refrain from or limit activities outside the home involving public contact. The latter suits the COVID-19 situation.

For this reason, the type of meaning of lockdown is idiomatic meaning in which it is interpreted non-literally.

\section{Data \#4}

"It is WHO view that all countries with community transmission should seriously consider postponing or reducing mass gatherings that bring people together..."

(WHO, 2020, Q\&A: Mass gathering and COVID-19)

From data 4, the compound word found is community transmission. The word includes the compound nouns due to the combination of a noun (community) and another noun (transmission).

The lexical meaning of the word community is a unified body of individuals, while transmission means an act, process, or instance of transmitting or the process of passing something from one person or place to another. After being combined, the meaning of community transmission is a situation where a country, territory, or area is experiencing larger outbreaks of local transmission. Therefore, the type of meaning that community transmission represents is literal meaning since the meaning derives from the literal meaning of each word.

\section{Compound verbs}

Data \#5

"Stay at home, self-isolate and monitor your symptoms."

(WHO, 2020, Q\&A on coronaviruses (COVID-19))

In the data, the compound word found is selfisolate. The category of the word is the compound verb. It is due to the combination of a noun (self) and a verb (isolate). Although Katamba (1993) does not mention the combination of a noun and a verb in the formation of a compound verb, this conclusion comes from one of the characteristics of a compound word that is the headword of the compound determines the word category of the compound.

On its own, the word self means oneself or itself or of oneself or itself. Meanwhile, the word isolate means to set apart from others or to be alone. The combination of the two creates the meaning of separating oneself from others or, in the case of COVID-19, separating an ill person 
from others. Therefore, the type of meaning selfisolate portrays is the literal meaning.

Data \#6

"What does it mean to self-quarantine?"

(WHO, 2020, Q\&A on coronaviruses (COVID-19))

From the data, the compound word found is self-quarantine. Its compound word category is the compound verb. It is because the word self is a noun while the word quarantine is in the word category of verbs.

Lexically, the word self means oneself or itself or of oneself or itself and the word quarantine means to detain in or exclude or to isolate from normal relations or communication. This combination of words creates the meaning of to isolate oneself. For this reason, the word selfquarantine is often mistaken as self-isolation.

Therefore, the WHO published an answer concerning the difference between the two. According to WHO, self-quarantine means restricting activities or separating people who are not ill themselves but may have been exposed to COVID-19. In this enlightenment, the sole difference between self-quarantine and selfisolation relies on the condition of a person that needs to be isolated. On this account, selfquarantine presents the type of meaning of semiidiomatic meaning.

Briefly, based on the analysis, it was found that there are two types of compound word categories, namely compound nouns and compound verbs. The percentages of occurrence of the two categories of compound word found are presented in Figure 1.

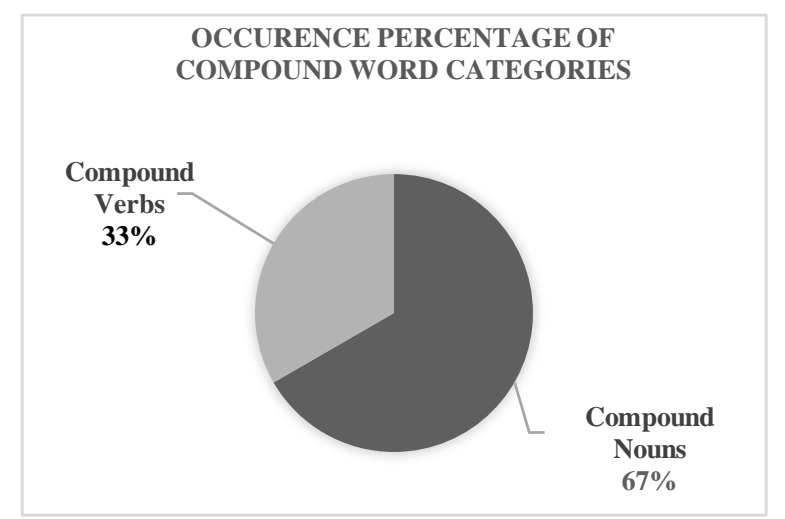

Figure 1. The occurrence of compound words

Meanwhile, in terms of meaning, there are three types of meaning found, including literal meaning, semi-idiomatic meaning, and idiomatic meaning. The percentages of the three types of meaning found are presented in Figure 2.

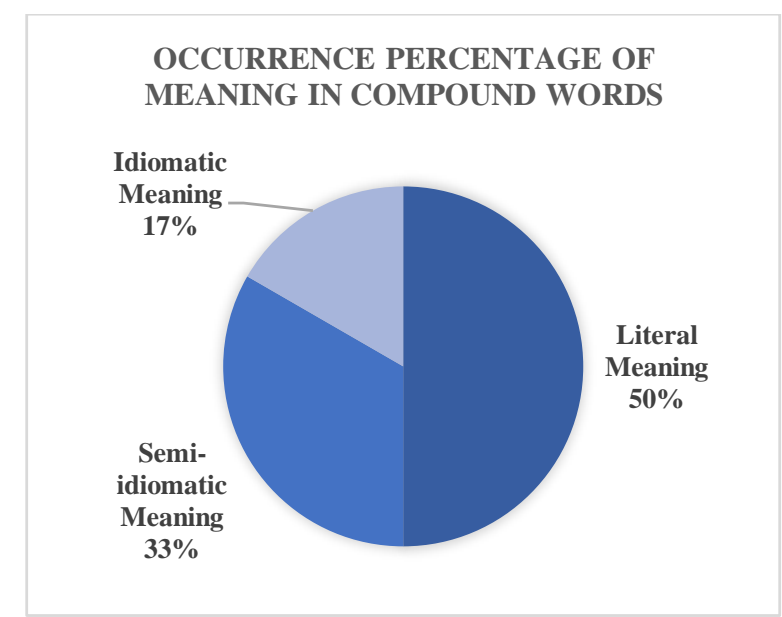

Figure 2. The percentage of meaning in compound words

\section{CONCLUSION}

Based on the analysis, it is found that there are two types of compound word, namely compound nouns (67\%) and compound verbs (33\%). On the other hand, there are three types of meaning, including literal meaning (50\%), semi-idiomatic meaning (33\%), and idiomatic meaning (17\%).

Additionally, it can also be concluded that in the category of compound nouns, the type of meaning that occurs frequently is literal meaning with the percentage of $50 \%$ followed by semiidiomatic meaning and idiomatic meaning with each percentage is $25 \%$. Moreover, the type of meaning that appears frequently in the category of compound verbs are literal meaning and semiidiomatic meaning with each percentage is $50 \%$ while idiomatic meaning does not occur.

This study also notes that as the COVID-19 progresses, the number of 'new' or 're-emerge' terms will also be increasing. Most of the terms' meanings are discoverable through news articles published massively on the internet.

\section{REFERENCES}

Akmajian, A., et al. (2001). An introduction to language and communication. MIT Press.

Aronoff, M., \& Fudeman, K. (2005). What is morphology? New Jersey: Blackwell Publishing Ltd.

Bauer, L. (1988). English word-formation. Cambridge: CUP.

Burling, R. (1992). Pattern of language structure, variation and change. San Diego: Academic Press.

Chaer, A. (1994). Pengantar semantik Bahasa Indonesia. Jakarta: Rineka Cipta.

Chaer, A. (2003). Linguistik umum. Jakarta: PT. Rineka Cipta.

Downing, A., \& Locke, P. (2006). English grammar $\left(2^{\text {nd }}\right.$ ed.). Abingdon: Routledge. 
ENGLISH REVIEW: Journal of English Education

Volume 8, Issue 2, June 2020
p-ISSN 2301-7554, e-ISSN 2541-3643 https://journal.uniku.ac.id/index.php/ERJEE

Hurford, J. R. (2007). Semantics: A coursebook. Cambridge: Cambridge University Press.

Quirk, et al. (1985). A comprehensive grammar of the English language. London: Longman.

Katamba, F. (1993). Modern linguistics: Morphology. Saeed, J. (1997). Semantics. USA: Blackwell Great Britain: Macmillan Press Ltd. Publisher, Inc.

Leech, G. N. (1974). Semantics: The study of meaning. Simatupang, E. C., \& Aulia, G. A. (2019). Syntactic Harmondsworth: Penguin Books.

Leech, G. N. (1981). Semantics $\left(2^{\text {nd }} e d.\right)$. Harmondsworth: Penguin Books.

Lyons, J. (1981). Language, meaning and context. Fontana.

McManis, C., et al. (1987). Language files: Materials for an introduction to language. Advocate Pub. Group.

Nazir, M. (2006). Metode penelitian. Jakarta: Ghalia.

O'Grady, et al. (1997). Contemporary linguistics. London and New York: Longman.

Palmer, F. R. (1983). Semantics. Cambridge: Cambridge University Press.

Payne, T. E. (1997). Describing morphosyntax: A guide for field linguists. Cambridge: Cambridge University Press.

Quirk, et al. (1978). Comprehensive grammar of the English language. England: Longman. and semantic analysis on slogans of aviation companies in ASEAN countries. English Journal Literacy Utama, 3(2), 123-131. doi: 10.33197/ejlutama.vol3.iss2.2019.273.

Spencer, A. (1999). Linguistics: An introduction. Cambridge: Cambridge University Press.

Spencer, A., \& Zwicky, A. M. (2001). The handbook of morphology. UK: Blackwell.

Trochim, W. M. L., \& Donnelly, J. P. (2006). The research methods knowledge base ( $3^{\text {rd }}$ ed.). Cornell University.

Whitney, E. L., \& Milholland, M. (1960). A four year continuation study of a teachers college class. Education Res.

Williams, M. J. (1975). Origins of the English language. New York: The Free Press.

Yule, G. (2006). The study of language. New York: Cambridge University Press. 
Ervina CM Simatupang \& Ida Zuraida Supri

Compound words that occur during the global pandemic covid-19: A morphosemantic study 